\title{
MODELLING OF STRUCTURE FORMING IN STRUCTURAL STEELS
}

\author{
Ye. G. Aftandiliants
}

National University of Life and Environmental Sciences of Ukraine. Ukraine.

Speciality of article: 131 - applied mechanics.

Corresponding author: aftyev@yahoo.com.

Article history: Received - August 2020, Accepted-October 2020.

Bibl. 19, fig. 19, tabl. 0.

Abstract. The study showed that the influence of alloying elements on the secondary structure formation of the steels containing from 0.19 to 0.37 wt. \% carbon; 0.82 1.82 silicon; 0.63-3.03 manganese; 1.01-3.09 chromium; $0.005-0.031$ nitrogen; up to 0.25 wt. $\%$ vanadium and austenite grain size is determined by their change in the content of vanadium nitride phase in austenite, its alloying and overheating above $t_{a c 3}$, and the dispersion of ferritepearlite, martensitic and bainitic structures is determined by austenite grain size and thermal kinetic parameters of phase transformations. Analytical dependencies are defined that describe the experimental data with a probability of $95 \%$ and an error of $10 \%$ to $18 \%$.

An analysis results of studying the structure formation of structural steel during tempering after quenching show that the dispersion and uniformity of the distribution of carbide and nitride phases in ferrite is controlled at complete austenite homogenization by diffusion mobility and the solubility limit of carbon and nitrogen in ferrite, and secondary phase quantity in case of the secondary phase presence in austenite more than 0.04 wt. \%. Equations was obtained which, with a probability of $95 \%$ and an error of 0.7 to $2.6 \%$, describe the real process.

Key words: structural steel, chemical composition, heat treatment, austenite, ferrite, perlite, martensite, bainite, phase transformations.

\section{Introduction}

The structural steel main operational properties are structurally sensitive. They depend on the characteristics of the structure that are formed during the casting solidification, their subsequent cooling and recrystallization in the solid state during heat treatment.

The primary structure parameters determine such important elements of the secondary structure as the dispersion and distribution of non-metallic inclusions, as well as the dispersion and distribution of segregation of alloying elements and impurities [1]. However, the main contribution to the formation of the secondary structure is made by the influence of alloying elements, impurities, modifiers, the type and conditions of heat treatment on the thermokinetic parameters of the secondary phase transformations and the decomposition kinetics of the supersaturated solid solution.

In the case of structural low- and medium-alloy steels, the formation of the casting structure during heat treatment can be carried out by diffusion pearlitic, diffusion-free martensitic, or mixed bainitic transformations and decomposition of a supersaturated solid solution. Structural quantitative characteristics are determined by the laws of nucleation of centers of new phases and their growth, in this case. These parameters were studied in studies [2-12].

Alloying elements and modifiers affect to nucleation rate of ferrite centers during pearlitic transformation $[6,8]$ and the growth rate of perlite $[10,15]$ as a result of changes of austenite stability to supercooling, specific energy of the interface, diffusion activation energy and degree of crystal structure defectiveness matrices.

It follows from the foregoing that, for all heat treatment types, structure formation in low- and mediumalloy structural steels is significantly affected by changes of alloying elements of parameters such as austenite grain size, its stability to supercooling, chemical interaction of elements, their solubility and diffusion mobility in solid solution, the defectiveness of the matrix crystal structure.

A lot of researches has been devoted to studying the influence of alloying elements, modifiers, and impurities on these parameters and their effect on the structure formation process $[2-5,10,13,14,15]$. However, the bulk of research covers dual and triple alloying systems. This excludes quantitative analytical forecasting of the influence of alloying elements, modifiers and impurities on the process of structure formation and structure characteristics in multicomponent industrial structural steels.

\section{Formulation of problem}

Based on the well-known conditions of the theory of alloying and modification [2-5, 13, 14], we can only qualitatively determine the direction of their influence on the structure formation process. Achieving the required steel structure requires experimental substantiation of the steel chemical composition, the type and thermal temporal conditions of their heat treatment.

Great theoretical and practical interest to conduct 
researches in direction of determination of the possibility of analytical prediction of the main structure characteristics for various types and thermal conditions heat treatment because it is absence of systematic studies of the relationship between the activity of alloying elements, modifiers and impurities and the process of structure formation in low- and medium-alloy structural steels.

The advantage of this approach to the problem is a significant reduction in the number of difficult to determine and controlled factors.

\section{Analysis of recent research results}

The formation of the required of the properties and operational characteristics of steels is achieved by alloying and modifying elements to reduce the structural heterogeneity of steel, increase the strength properties of the solid solution and the degree of dispersion hardening of the metal.

The secondary phase precipitation is the most effective hardening of such hardening mechanisms as the effect of elements on the strength of the solid solution, the density of dislocations, grain-boundary and dispersion hardening [16].

The main task of alloying and modification is to ensure dispersed and uniform second phase precipitation during heat treatment from the point of view of increasing strength. This is achieved as a result of the structure dispersion for account of increasing of alloying of austenite stability to supercooling, a decreasing activity and diffusion mobility of carbon, and a change of the type and crystallographic parameters of the carbide phase.

The performed analysis shows that for the complex formation of a favorable ratio of a high level of strength and plastic properties of steels with a minimum consumption of alloying elements, the chemical composition of the steel, the modification and heat treatment regimes should ensure dispersion of all structural elements.

In connection with the foregoing, it is necessary to study the effect of alloying and modifying elements, heat treatment regimes, thermodynamic and kinetic parameters of phase transformations on the laws of structure formation and characteristics of dissolution and precipitation of secondary phases in solid solution.

\section{Purpose of research}

The article presents a method for solving the problem of eliminating the oscillations of the load on the articulated suspension during the simultaneous movement of the two links of the boom system, namely the lifting of the handle and reducing the departure of the telescopic section.

\section{Results of research}

Austenitic structure. After the austenite formation austenite grains increase during further heating or isothermal aging. A result analysis of the works devoted to thermodynamics, kinetics, and the structure of grain boundaries [17-19] shows that the speed of movement of grain boundaries is mainly associated with two integral factors: a change in the free energy of the system and the efficiency of interaction of grain boundaries with atoms of elements in a solid solution and particles of the secondary phase.

Based on the above assumptions, we determined the quantitative regularity of the factor influence such as the content of elements in the solid solution $\left(\mathrm{C}, \mathrm{Si}, \mathrm{Mn}, \mathrm{Cr}, \mathrm{V}_{\mathrm{a}}\right.$, $\mathrm{N}_{\mathrm{a}}$ ), steel overheating above the temperature of the end of austenite formation $\Delta \mathrm{t}$ ), and the content of the nitridevanadium phase in austenite ( $\mathrm{q}_{\mathrm{VNa}}$ ) on the dispersion of the austenitic structure $\left(\mathrm{D}_{\text {aust }}\right)$ in the temperature range from 900 to $1050{ }^{\circ} \mathrm{C}$ after exposure 2 hours.

The quantitative regularity of such an influence has the following form:

$\mathrm{D}_{\text {aust }}=24,7-410 \cdot \mathrm{q}_{V N a}-132 \cdot \mathrm{C} \cdot \mathrm{Si}+24,2 \cdot \mathrm{C} \cdot \mathrm{Mn}+$

$+11210 \cdot \mathrm{C} \cdot \mathrm{N}_{\mathrm{a}}+15,2 \cdot \mathrm{Si} \cdot \mathrm{Cr}-326 \cdot \mathrm{Si} \cdot \mathrm{V}_{\mathrm{a}}+2589 \cdot \mathrm{Si} \cdot \mathrm{N}_{\mathrm{a}}+$

$0,0529 \cdot \mathrm{Si} \cdot \Delta \mathrm{t}+410 \cdot \mathrm{Si} \cdot \mathrm{q}_{V N a}-1,76 \cdot \mathrm{Mn} \cdot \mathrm{Cr}-0,0158 \cdot \mathrm{Mn} \cdot \Delta \mathrm{t}+$

$+420 \cdot \mathrm{Cr} \cdot \mathrm{V}_{\mathrm{a}}-4494 \cdot \mathrm{Cr} \cdot \mathrm{N}_{\mathrm{a}}-546 \cdot \mathrm{q}_{V N a} \cdot \mathrm{Cr}-2,31 \cdot \Delta \mathrm{t} \cdot \mathrm{V}_{\mathrm{a}}+$

$$
+1,02 \cdot 10^{-3} \cdot \Delta \mathrm{t}^{2}+3048 \cdot \mathrm{q}_{V N a}{ }^{2}+3,71 \cdot \Delta \mathrm{t} \cdot \mathrm{q}_{V N a},
$$$$
\mathrm{R}=0.942 ; \delta=18 \% ; \mathrm{F}_{\mathrm{c}}=54,9>\mathrm{F}_{\mathrm{T}}=1.8 \text {. }
$$

where: $\mathrm{R}$ is the multiple correlation coefficient; $\delta$ - the average relative error of approximation; $F_{p}, F_{T}$ are the estimated and tabulated values of the Fischer's criterion.

The established regularity (1) makes it possible to differentiate the effect of the steel chemical composition associated with solid-state action and a change of secondary phase quantity in austenite at various degrees of its overheating. The calculation results show that the combination of initial factors is such that alloying of 20KhGSL steel by C, Mn, Cr, V leads to dispersion, while by nitrogen and silicon lead to an increase of the austenite grain of structural steels under the studied conditions (fig. 1).

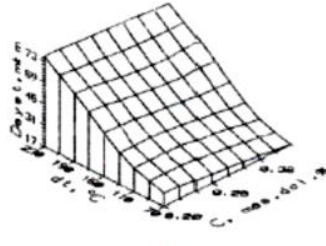

a

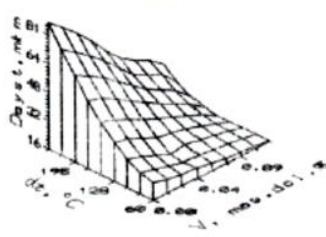

c

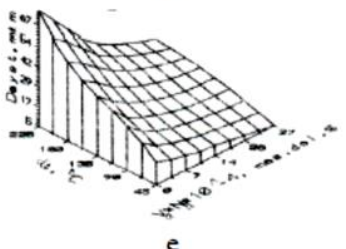

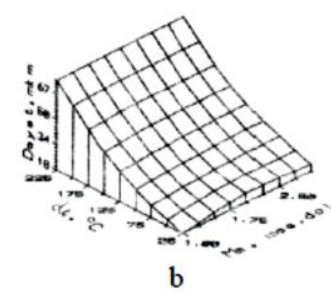

b
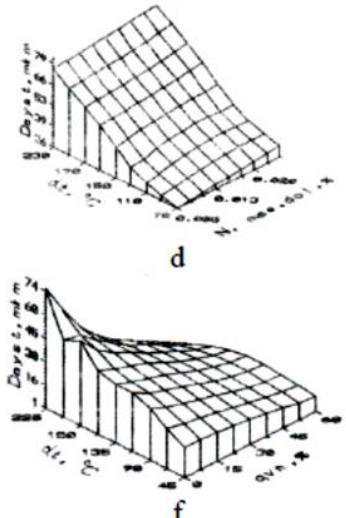

Fig. 1. The influence of the carbon (a), manganese (b), vanadium (c), nitrogen (d), vanadium and nitrogen in austenite (e), vanadium nitrides in austenite (f) on austenite grain sizes.

The base steel contains (wt.\%) $0.2 \mathrm{C}, 1 \mathrm{Si}, 1 \mathrm{Mn}, 1 \mathrm{Cr}$. 
The nitrogen and silicon abnormal effect is associated with a change of the carbon thermodynamic activity. Nitrogen and vanadium substantially grind of the austenitic structure upon joint alloying of both solid solution and in the form of a secondary phase.

Comparing the solid solution action of alloying elements with the influence of the nitride-vanadium phase, it should be noted that with increasing overheating, the effectiveness of the influence of elements dissolved in austenite decreases, and the effect of the nitride-vanadium phase is characterized by a different pattern. Figure 1 data show that when the content of the nitride-vanadium phase in austenite is up to $30 \%$ (of its maximum possible quantity), overheating above $\mathrm{t}_{\mathrm{ac} 3}$ up to $135^{\circ} \mathrm{C}$ leads to a slight coarsening of the austenite grains, the sizes of which is subsequently stabilized by vanadium nitrides and practically does not change.
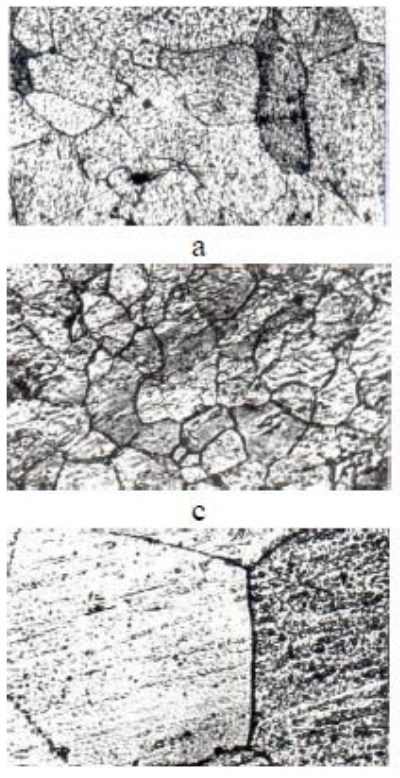

e

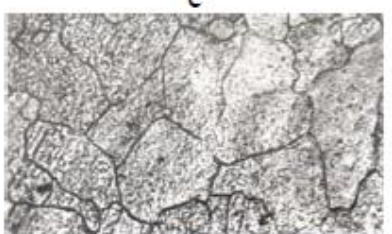

$\mathrm{g}$

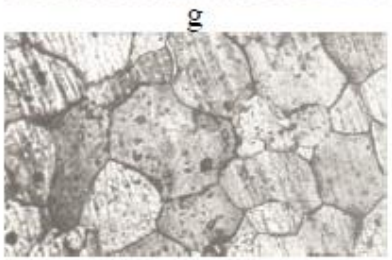

i

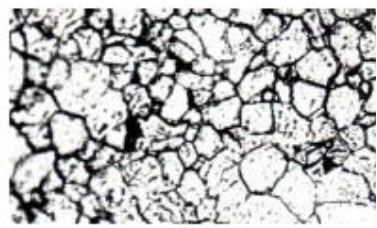

b

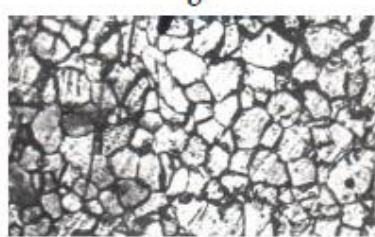

d

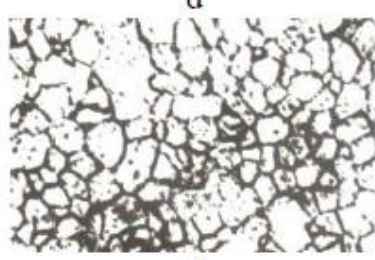

f

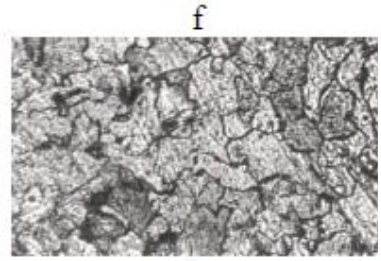

h

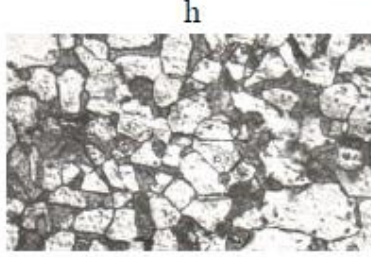

j
Fig. 2. Austenite grains of the steels 20KhGSL (a), 20KhGSAFL (b), 40KhGSL (c), 40KhGSAFL (d), 20KhGS3L (e), 20KhGS3AFL (f), 20KhG3SL (g), 20KhG3SAFL (h), 20Kh3GSL (i), 20Kh3GSAFL (j), after holding during 2 hours at $950{ }^{\circ} \mathrm{C}$. Magnification 500 times.

It should be noted that with increasing heating temperature, the nitrogen and vanadium dispersing effect increases. Alloying steel by nitrogen and vanadium and obtaining a sufficient quantity of nitride-vanadium phase (at least $30 \%$ ) is an effective method of increasing the structural steel uniformity, stabilizing and dispersing of austenite grains. At the same time, by targeted alloying of steels containing nitrogen and vanadium, it is possible to enhance or weaken the effect of nitrogen and vanadium, since steel alloying by silicon leads to an increasing, and carbon, manganese, and chromium to a decreasing of the nitride-vanadium phase quantity in austenite. Examples of the element effect on the nitrogen and vanadium dispersant effect are shown in fig. 2.

It should be noted the significant influence of the quantity of alloying elements in steel. For example, a change in the chemical composition of base steel from $20 \mathrm{KhGSL}$ to $30 \mathrm{Kh} 2 \mathrm{G} 2 \mathrm{~S} 2 \mathrm{~L}$ leads not only to a change in efficiency, but also to the direction of the alloying effect on the dispersion of austenite grain. Calculations show that in this case, the carbon influence increases, the nitrogen action direction changes, and the effect of silicon, manganese, chromium, and vanadium becomes extreme. Alloying by chromium to $2.4 \%$ and vanadium to $0.1 \%$ leads to a decreasing, and subsequently to $3 \%$ and $0.2 \%$, respectively, to an increasing of the austenite grain size. Silicon and manganese have the opposite effect with maximum efficiency at $2.4 \%$ of the quantity of each element in steel.

Ferrite-pearlite structure. Accept to attention that the ferrite-pearlite structure grain size $\left(D_{\mathrm{fp}}\right)$ depends from the dispersion of the austenitic structure $\left(\mathrm{D}_{\text {aust }}\right)$ and the thermokinetic parameters of $\gamma \rightarrow \alpha+$ perlite transformation, we determined the quantitative laws of this effect. Multiple correlation analysis shows that the considered factors influence to grain size of the ferritepearlite structure as follows.

$D_{f p}=1,27 \cdot \mathrm{D}_{\text {aust }}-20,3-0,654 \cdot \mathrm{t}_{\mathrm{ar} 1}+0,661 \cdot \mathrm{t}_{\mathrm{ar} 3}-$

$-5,75 \cdot \tau_{r}$

$\mathrm{R}=0.901 ; \delta=16.9 \% ; \mathrm{F}_{\mathrm{p}}=21.7>\mathrm{F}_{\mathrm{T}}=2.9$,

where $\mathrm{t}_{\mathrm{ar} 3}, \mathrm{t}_{\mathrm{ar} 1}$ and $\tau$ are start and finishing temperature, and duration of diffusion austenite dissolution, respectively.
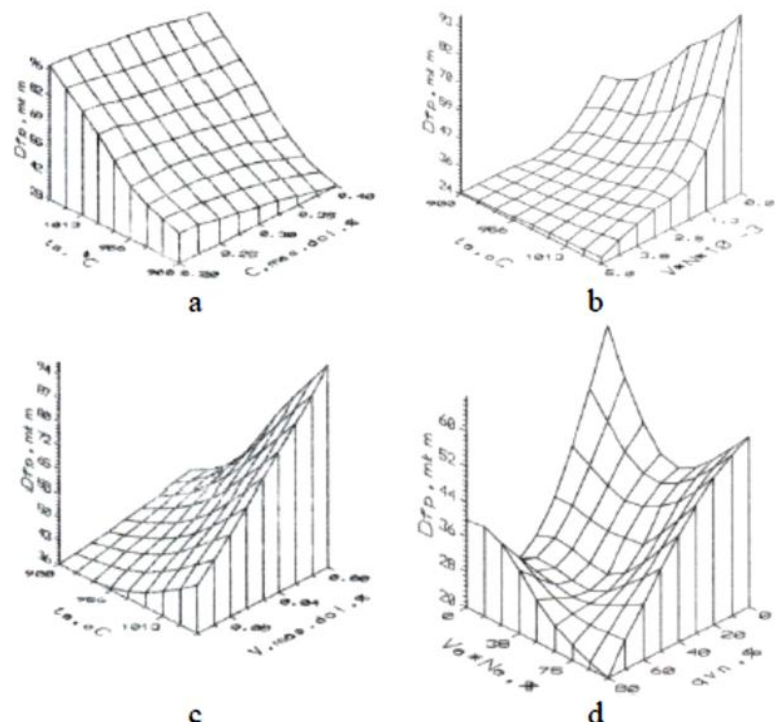

c

d

Fig. 3. The influence of the carbon (a), vanadium and nitrogen (b), vanadium (c), vanadium and nitrogen, in austenite, vanadium nitrides in austenite (d) on ferrite - perlite grain sizes.

The base steel contains (wt.\%) $0.2 \mathrm{C}, 1 \mathrm{Si}, 1 \mathrm{Mn}, 1 \mathrm{Cr}$. 
The formula 2 analyses shows that the ferrite-pearlite structure dispersion occurs with an increasing of carbon, manganese, chromium, vanadium and nitrogen quantity in steel, and enlargement - silicon. The element effect laws are shown on fig. 3 at different temperatures of austenitizing heating $\left(\mathrm{t}_{\mathrm{a}}\right)$ and cooling at a rate of $40^{\circ} \mathrm{C} / \mathrm{min}$.

The established regularity shows that on the ferritepearlite structure grain size the element effect is associated not only with their content in steel, but also with the temperature of austenitic heating. The elements can be arranged in the following sequence: $\mathrm{Mn}, \mathrm{Cr}, \mathrm{C}, \mathrm{V}, \mathrm{N}$ according with the specific efficiency of grinding the structure after heating to $900{ }^{\circ} \mathrm{C}$, and $-\mathrm{Cr}, \mathrm{Mn}, \mathrm{C}, \mathrm{V}, \mathrm{N}$ after heating to $1050{ }^{\circ} \mathrm{C}$.

Fig 3 data show that the joint alloying of steel by nitrogen and vanadium leads to their almost additive effect and is the most significant in the alloying systems considered. Moreover, the maximum dispersing effect is observed when about $50 \%$ of nitrogen and vanadium are dissolved in austenite and their same content in the form of vanadium nitrides (fig. 3d).

On fig. 4, 5 are shown the examples of element effect on the ferrite-pearlite structure dispersion.

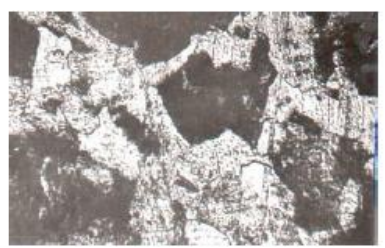

a

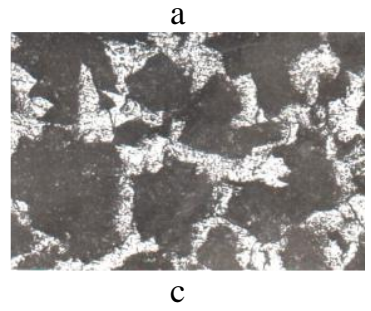

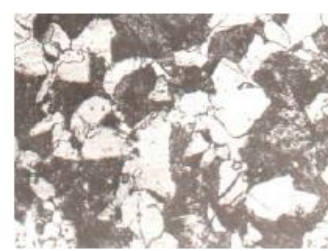

b
Fig. 4. Ferritepearlite structure of steels 20KhGSL (a), 40KhGSL 20KhGS3L (c) after austenitization at 900 ${ }^{\circ} \mathrm{C}$. The cooling rate is $40{ }^{\circ} \mathrm{C} / \mathrm{min}$

Magnification-300

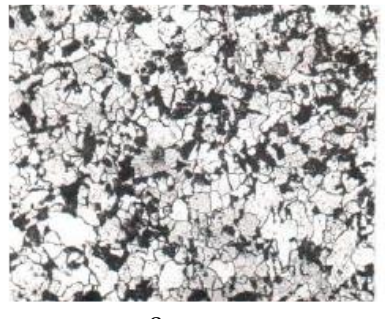

a

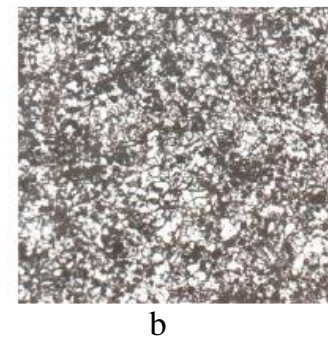

b
Fig. 5. Ferrite-pearlite structure of steels $20 \mathrm{KhGSL}$ (a) and 20KhGSAFL (b) after austenitization at $900{ }^{\circ} \mathrm{C}$. The cooling rate is $40^{\circ} \mathrm{C} / \mathrm{min}$. Magnification- 100

Martensitic structure. The martensitic transformation is a diffusionless transition of austenite to a supersaturated solid solution of carbon ferrite. Martensite crystals grow within the original austenitic grain. However, their length is determined not only by the dispersion of the austenitic structure, but also by the presence of defects in the crystal structure, since it is known that an increase in imperfections in the crystal structure leads to dispersion of the martensitic structure [10].
Consequently, the effect of the chemical composition of steel on the dispersion of the martensitic structure should be associated with a change of the austenite grain size and the development of crystal structure defects. Assuming that the number of defects in the crystalline structure of a solid solution is proportional to the content of alloying elements and secondary phases in it, we determined the law of such an effect on the dispersion of the martensitic structure of structural steels. The integral characteristic of the martensitic structure was the length of the martensite needles $\left(\mathrm{l}_{\mathrm{m}}\right)$.

Mathematical analysis showed that the dispersion of the martensitic structure with a probability of $95 \%$ is determined by the austenite grain size $\left(D_{\text {aust }}\right)$ and the nitrogen content $\left(\mathrm{N}_{\mathrm{a}}\right)$ in it.

$$
\begin{aligned}
& l_{m}=3,8+0,856 \cdot \mathrm{D}_{\text {aust }}-298 \cdot \mathrm{N}_{\mathrm{a}}, \\
& \mathrm{R}=0.99 ; \delta=10.3 \% ; \mathrm{F}_{\mathrm{p}}=655>\mathrm{F}_{\mathrm{T}}=3.4,
\end{aligned}
$$

The formula 3 analysis shows that alloying of 20KhGSL steel by carbon, chromium and vanadium leads to dispersion, and silicon, manganese to the enlargement of the martensitic structure (Fig. 6).

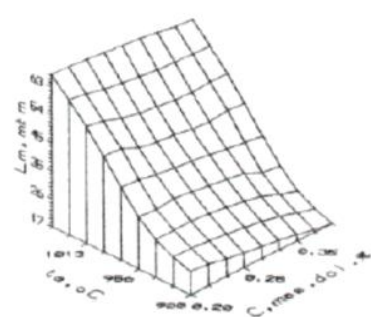

a
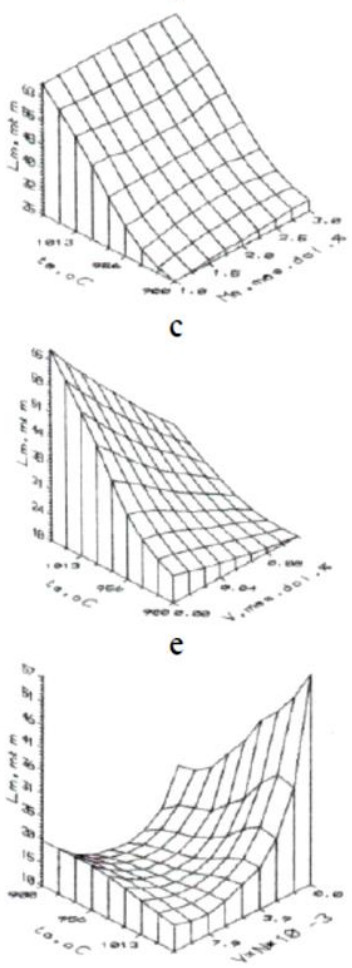

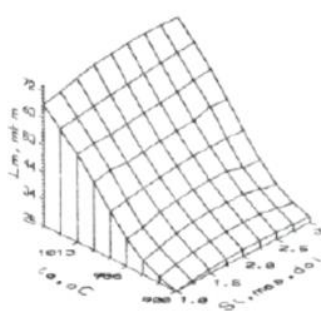

b
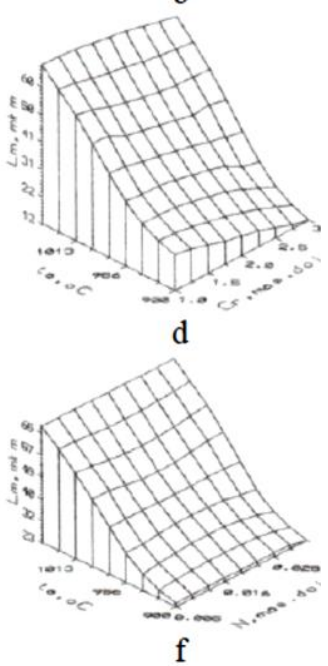

f

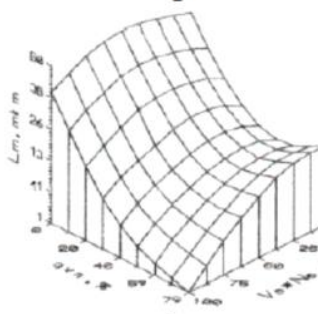

Fig. 6. The influence of the carbon (a), silicon (b), manganese (c), chrome (d), vanadium (e), nitrogen (f), vanadium and nitrogen in austenite $(\mathrm{g})$, vanadium nitrides in austenite $(\mathrm{h})$ on length of martensite needles.

The base steel contains (wt.\%) $0.2 \mathrm{C}, 1 \mathrm{Si}, 1 \mathrm{Mn}, 1 \mathrm{Cr}$. 
The nitrogen content increasing in 20KhGSL steel has practically no effect on the dispersion of martensite (Fig. 6).

The complex alloying of 20KhGSL steel by nitrogen and vanadium leads to efficient grinding of the martensitic structure (Fig. 6). It should be noted that alloying steel by nitrogen and vanadium more than $\mathrm{V} \cdot \mathrm{N}=8 \cdot 10^{-3}$ (wt., \%), the austenitization temperature of steel in the range from 900 to $1050{ }^{\circ} \mathrm{C}$ practically does not affect to the martensite needle length.

Analyzing the solid-solution $\left(\mathrm{V}_{\mathrm{a}} \cdot \mathrm{N}_{\mathrm{a}}\right)$ and dispersion ( $\mathrm{qvN}_{\mathrm{vN}}$ ) effects of nitrogen and vanadium, it should be noted that the maximum modifying effect is achieved at $40-50 \%$ nitrogen and vanadium content in the form of nitrides and, correspondingly, $60-50 \%$ dissolution of elements in austenite (Fig. 6).

Differentiation of the effect of nitrogen and vanadium in the solid solution state $\left(\mathrm{V}_{\mathrm{a}} \cdot \mathrm{N}_{\mathrm{a}}\right)$ and in the form of a secondary phase $\left(\mathrm{q}_{\mathrm{vN}}\right)$ shows that the maximum effect is observed at $40-50 \%$ of the contribution of each factor (Fig. 6).

Examples of the influence of the chemical composition and austenitization temperature on the dispersion of the martensitic structure of structural steels are shown in fig. 7,8 .

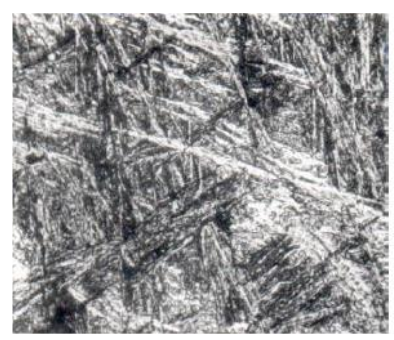

a

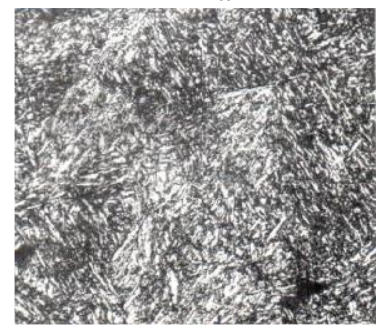

c

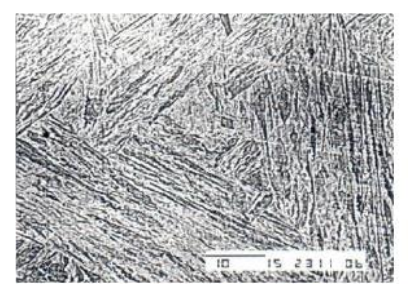

a

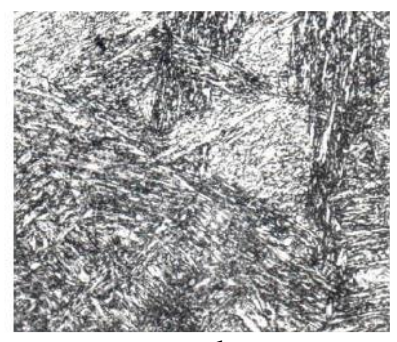

b

Fig. 7. Martensitic structure of the steels 20KhGS3L (a), 20KhG3SL (b) 20Kh3G3SL (c) after normalization of $1000^{\circ} \mathrm{C}$. Magnification 300 times.

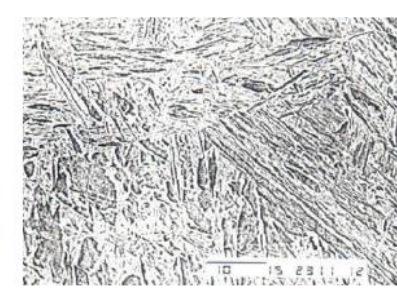

b
Fig. 8. The nitrogen and vanadium (b) influence on the martensitic structure of steel 20KhG3SL (a) after normalization from $1000{ }^{\circ} \mathrm{C}$.

Bainitic structure. Between the zone of hightemperature pearlitic and low-temperature martensitic transformations, there is an intermediate or bainitic transformation zone, which proceeds in a complex combination of shear displacements for formation of a body-centered $\alpha$ - iron lattice with carbon diffusion movement for forming carbide particles. The bainitic transformation in alloy steels consists of the carbon diffusion redistribution in austenite, the diffusionless $\gamma \rightarrow \alpha$ - iron transition, and the formation of carbides in ferrite.

The diffusion and diffusion-free austenite decomposition depends of substantially from defect numbers in the crystalline structure of the solid solution and the austenite grain dispersion. Therefore, the influence of alloying elements on the formation of a bainitic structure should be associated with their change of the defect numbers in the austenite crystalline structure, its grain sizes, and also the diffusion carbon mobility in austenite at the start of bainite formation.

Assuming that in the austenite crystalline structure the defect numbers are proportional to alloying element quantity in it, the above assumption was checked on steels containing from 0.19 to 0.37 wt. \% of carbon; 0.82-1.82 silicon; 0.63-3.03 manganese; 1.01-3.09 chromium; 0.0050.031 nitrogen; to $0.25 \%$ vanadium, after normalization from $950{ }^{\circ} \mathrm{C}$. The response function was taken the ferrite needle length $\left(l_{\mathrm{fn}}\right)$ in bainite.

A performed analysis of the experiment results show that the dispersion of a bainitic structure is described by the following quantitative regularity, with a probability of $99 \%$

$$
\begin{gathered}
l_{f n}=4,85+1,19 \cdot \mathrm{D}_{\text {aust }}+516 \cdot \mathrm{N}_{\mathrm{a}}+ \\
+0,017 \cdot \mathrm{D}_{\text {aust }} \cdot \ln D_{\gamma}^{C}-8,34 \cdot 10^{-4} \cdot \mathrm{D}_{\text {aust }} \cdot t_{s b}, \\
\mathrm{R}=0.821 ; \delta=15.8 \% ; \mathrm{F}_{\mathrm{p}}=13>\mathrm{F}_{\mathrm{T}}=4.2,
\end{gathered}
$$

where: $D_{\gamma}^{C}$ - carbon diffusion coefficient in austenite, $\mathrm{t}_{\mathrm{sb}}$ bainite start temperature, ${ }^{\circ} \mathrm{C}$,
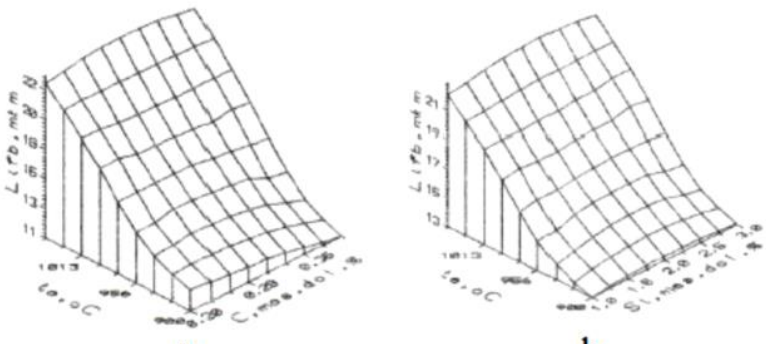

a

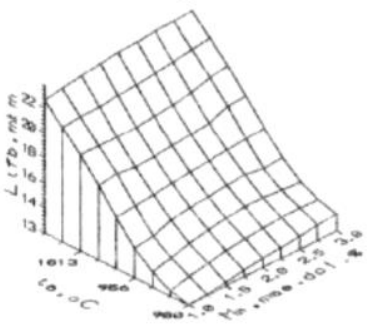

b

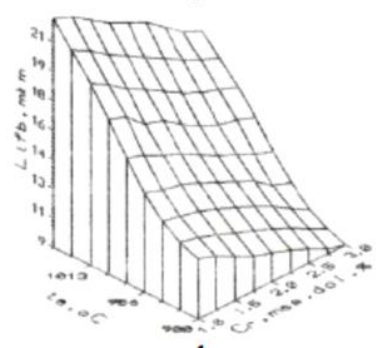

c
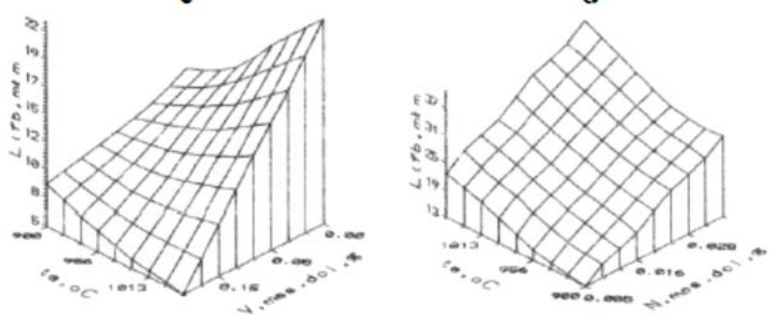

f

Fig. 9. The influence of the austenization temperature and carbon (a), silicon (b), manganese (c), chrome (d), vanadium (e), nitrogen (f) on length of ferrite needles in bainite.

The base steel contains (wt.\%) $0.2 \mathrm{C}, 1 \mathrm{Si}, 1 \mathrm{Mn}, 1 \mathrm{Cr}$. 
The influence of the element effectiveness was determined on the ferrite needle sizes of the bainitic structure of structural steels after normalization at various austenitization temperatures. The base was steel 20KhGSL. The calculation results are shown in fig. 9.

It is seen that an increasing of chromium, carbon and vanadium quantity in steel leads to a decreasing of ferrite needle sizes in bainite, silicon has practically no effect, and manganese and nitrogen alloying leads to an enlargement of the bainitic structure.

Joint nitrogen and vanadium alloying leads to dispersion of bainite needles at additives of less than $\mathrm{V} \cdot \mathrm{N}$ $=(3-4) \cdot 10^{-3} \mathrm{wt} . \%$. The ferrite needle sizes does not change at large additions of nitrogen and vanadium in steel, practically, and it increases with additions more than $\mathrm{V} \cdot \mathrm{N}$ $=(8-11) \cdot 10^{-3}$ wt. $\%$.

An analysis of the nitrogen and vanadium effect dissolved in austenite $\left(\mathrm{V}_{\mathrm{a}} \cdot \mathrm{N}_{\mathrm{a}}\right)$ and in the form of vanadium nitrides $\left(\mathrm{q}_{\mathrm{vN}}\right)$ shows that the maximum modifying effect is achieved when $20-30 \%$ vanadium nitrides of the maximum possible quantity in steel are present in austenite.

Examples of the influence of the chemical composition and austenitization temperature on the dispersion of a bainitic structure are shown in fig. 10 .
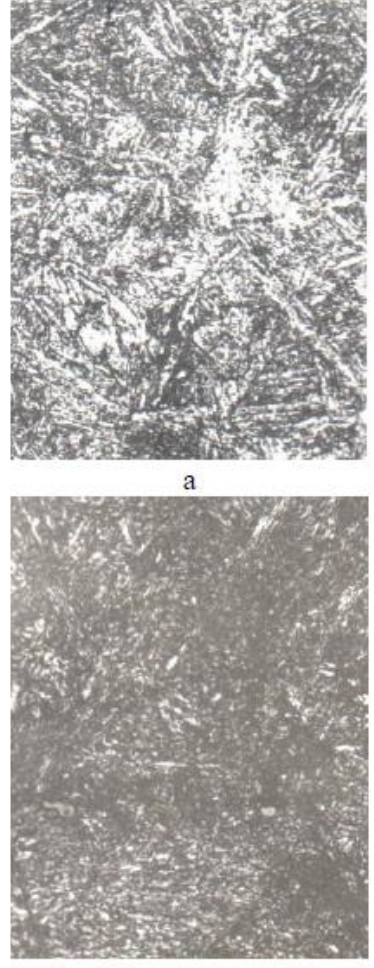

c

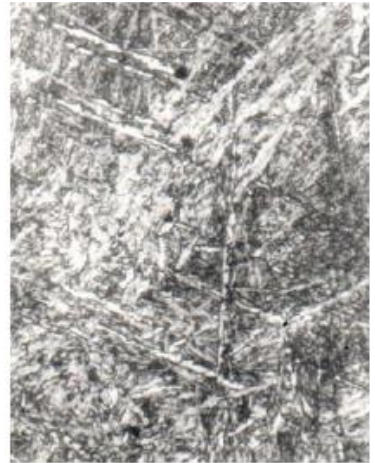

b

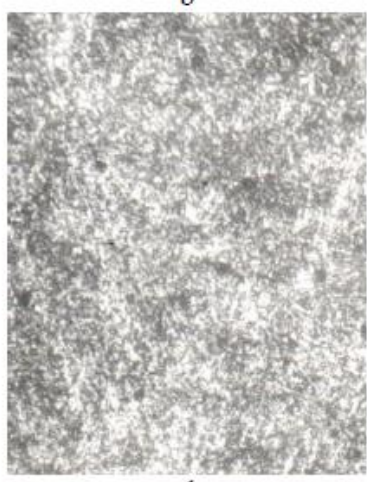

d
Fig. 10. The austenitization temperature $\left(t_{a}\right)$ influence on the bainitic structure of steels 40Kh3GSL

$(\mathrm{a}, \mathrm{b})$ and 40Kh3GSAFL (c, d). Magnification - 300 times. $\mathrm{a}, \mathrm{c}-\mathrm{t}_{\mathrm{a}}=900{ }^{\circ} \mathrm{C} ; \mathrm{b}, \mathrm{d}-\mathrm{t}_{\mathrm{a}}=1000{ }^{\circ} \mathrm{C}$.

Structural steel structure after quenching and tempering. During tempering of quenching steel, redistribution of carbon atoms in martensite to dislocations and interstitial sites of the crystal lattice occurs, martensite decomposes with the formation of carbon enriched areas, and then carbide precipitates; changes in the structure and composition of carbides, their relationship with the matrix, and the precipitation of dispersed carbide and nitride particles from a solid solution (secondary hardening).

During low-temperature (up to $350{ }^{\circ} \mathrm{C}$ ) tempering, the process of martensite decomposition is limited by the redistribution of carbon and relaxation of elastic stresses. As a result of this tempering, the tempered martensite structure does not practically differ from the quenching martensite structure [15].

A metallographic analysis of the martensitic structure of structural steels after quenching and tempering at 350 ${ }^{\circ} \mathrm{C}$ showed that the established law of the alloying element influence on the martensitic structure dispersion was formed during continuous cooling is also preserved for tempering martensite.

Steel microstructures are shown in fig. 11.

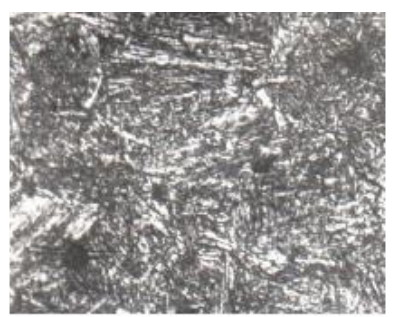

a

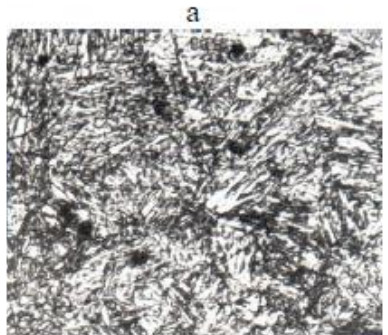

c

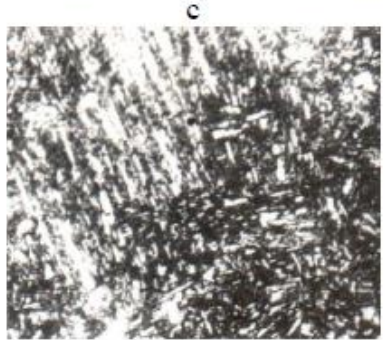

e

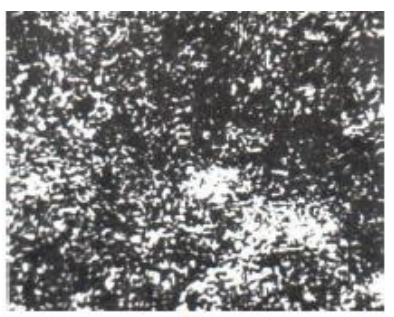
b

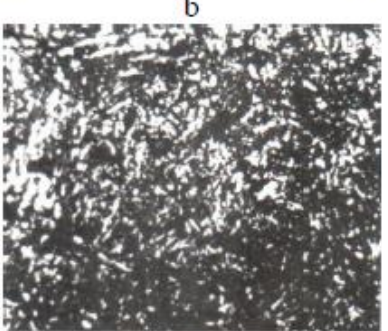

d

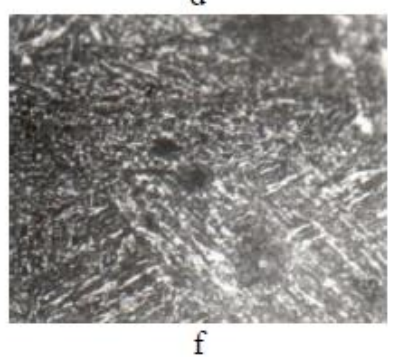

Fig. 11. Microstructure of steels 20KhGSL (a), 20KhGSAFL (b) 20KhGS3L (c), 20KhGS3AFL (d), 20KhG3SL (e), 20KhG3SAFL (f) after quenching and tempering at $350{ }^{\circ} \mathrm{C}$. Magnification -300 times.

The research results show that at carbon quantity increasing carbides grow and carbide phases accumulate. The dispersion and distribution uniformity increase in the case of additional steel alloying by manganese, chromium and silicon (Fig. 12).

Analysis of the morphology of the secondary phases formed during the doping of the metal with nitrogen and vanadium shows that in addition to the carbide particles in the steel, the nitride phase $\mathrm{VN}$ is isolated (Fig. 13).

In this case, a more uniform distribution of the dispersed carbide phase is observed.

Taking as independent factors the solubility of carbon and nitrogen and their diffusion mobility in ferrite, as well as the content of vanadium nitrides quantity not dissolved in austenite ( $\mathrm{q}_{\mathrm{VNa}}$ ) and precipitated in ferrite ( $\mathrm{q}_{\mathrm{VNf}}$ ), quantitative laws of the influence of these factors on the 
dispersion and distribution of the carbide and nitridevanadium phases were determined.

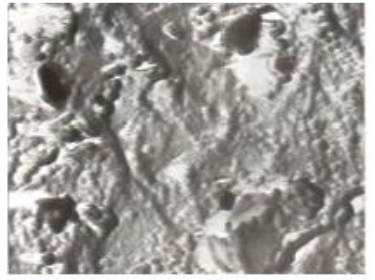

a

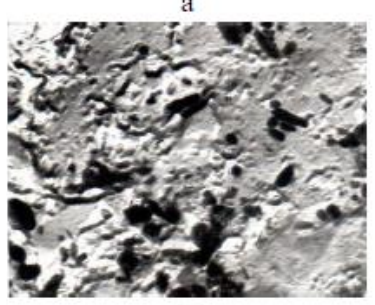

c

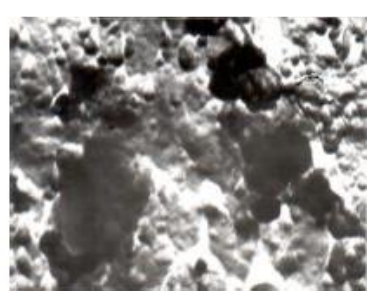

b

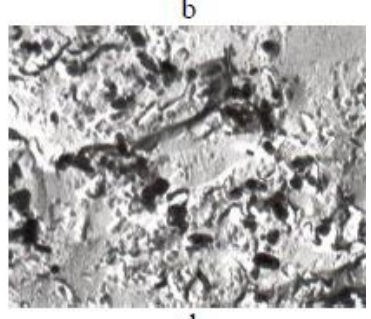

d
Fig. 12. Carbide phases in steels 20KhGSL (a), 40KhGSL (b) 20KhG3SL (c), 20KhGS3L (d) after quenching at $950{ }^{\circ} \mathrm{C}$ and tempering at $650{ }^{\circ} \mathrm{C}$. Magnification - 19000 times.

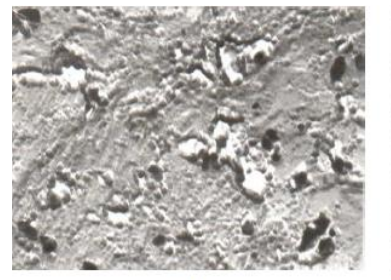

a
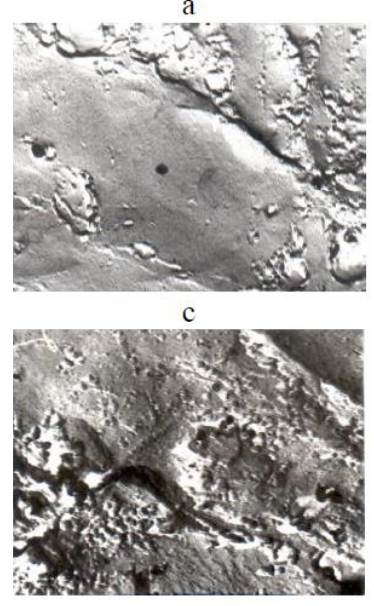

e

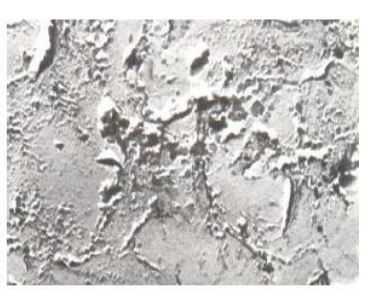

b

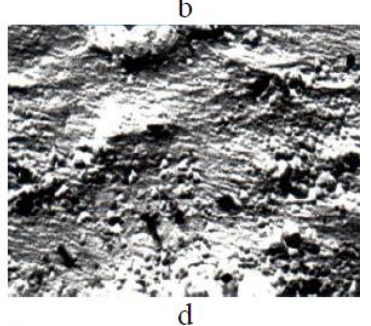

d

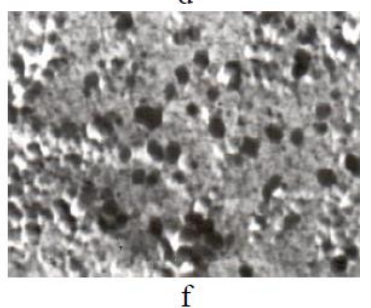

Fig. 13. The nitride and carbide phases in steels 20KhGSAFL (a), 40KhGSAFL (b) 20KhG3SAFL (c), 20KhGS3AFL (d), 20Kh3GSAFL (e) and vanadium nitrides in Armco iron (f) after quenching at $950{ }^{\circ} \mathrm{C}$ and tempering at $650{ }^{\circ} \mathrm{C}$.

Magnification: a-e - 27000 times; $\mathrm{d}-39000$ times.

The mathematical analysis results show that in the absence of a secondary phase in ferrite prior to the initiation of nitride or carbide formation, the dispersion and distribution of the carbide and nitride phases in ferrite is determined by diffusion mobility and the solubility limit of carbon and nitrogen in ferrite according to the following equations:

$$
\begin{aligned}
& d_{c}=294,8+23,8 \cdot \ln D_{f}^{C}+0,48 \cdot\left(\ln D_{f}^{C}\right)^{2} \\
& \mathrm{R}=0.952 ; \delta=3,7 \% ; \mathrm{F}_{\mathrm{p}}=28,8>\mathrm{F}_{\mathrm{T}}=10,1
\end{aligned}
$$

$$
\begin{aligned}
& d_{V N}=0,9+5 \cdot 10^{-2} \cdot \ln D_{f}^{N}+7,4 \cdot 10^{-5} \cdot\left(\ln D_{f}^{N}\right)^{2},(6) \\
& \mathrm{R}=0.95 ; \delta=5,7 \% ; \mathrm{F}_{\mathrm{p}}=14>\mathrm{F}_{\mathrm{T}}=9,6 . \\
& \lambda_{c}=-4,9+29 \cdot \lg [C]_{d}+1,2 \cdot \lg [C]_{d} \cdot \ln D_{f}^{C}+9 \cdot d_{c},(7) \\
& \mathrm{R}=0.999 ; \delta=0,7 \% ; \mathrm{F}_{\mathrm{p}}=59,1>\mathrm{F}_{\mathrm{T}}=19,2 . \\
& \lambda_{V N}=2,3 \cdot \lg [N]_{d}+3 \cdot 10^{-2} \cdot \lg [N]_{d} \cdot \ln D_{f}^{N}+23 \cdot d_{V N}- \\
&-1, \\
& \quad \mathrm{R}=0.994 ; \delta=2,6 \% ; \mathrm{F}_{\mathrm{p}}=51,5>\mathrm{F}_{\mathrm{T}}=19,2 .
\end{aligned}
$$

where: $d_{c}, d_{V N}$ and $\lambda_{c}, \lambda_{V N}-$ size and interparticle distance between vanadium carbides and nitrides, respectively; $[C]_{d},[N]_{d}$ and $D_{f}^{C}, D_{f}^{N}-$ solubility limits and diffusion coefficients of carbon and nitrogen in ferrite, respectively.

Taking 20KhGSL steel as the base, we determined the efficiency of the influence of elements and tempering temperature on the dispersion (fig. 14, 15) and distribution (fig. 16, 17) of the carbide (fig. 14, 16) and nitridevanadium (fig. 15, 17) phases in the improved structural steels.

The calculation results show that according to the dispersion efficiency of the carbide and nitride-vanadium phases, the elements can be arranged in the following sequence: for carbides - $\mathrm{Si}, \mathrm{Mn}, \mathrm{Cr}$; for vanadium nitrides - Mn, Cr, C, Si. In the case of interparticle distances, chromium and silicon increasing leads to a regular decreasing, and manganese - leads to an increasing of the distance between the particles of vanadium nitrides and carbides.

Analysis shows that tempering temperature influence on the changing of the distance between carbide particles and the process of their formation ends mainly at $650{ }^{\circ} \mathrm{C}$ and a further tempering temperature increasing is accompanied by coagulation of the carbide phases.

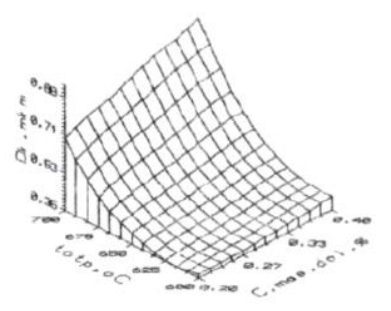

a

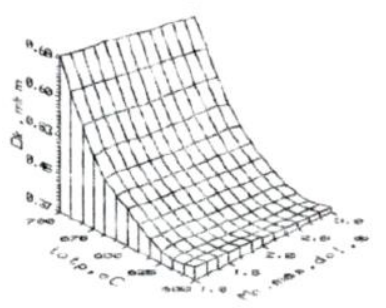

c

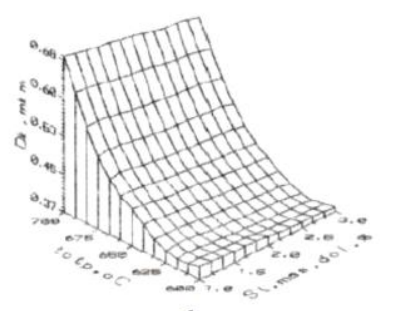

b

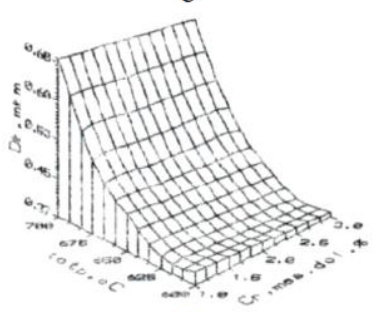

d
Fig. 14. The carbon (a), silicon (b), manganese (c), chromium (d) and tempering temperature influence on carbide sizes.

The base steel contains (wt. \%) $0.2 \mathrm{C}, 1 \mathrm{Si}, 1 \mathrm{Mn}$, $1 \mathrm{Cr}$.

In the case when a secondary phase is present in the solid solution, for example, vanadium nitrides ( $\mathrm{q}_{\mathrm{vN}(\mathrm{aust})}$ ), which did not dissolve at heating for quenching, in a quantity of 0.039 to $0.070 \mathrm{wt}$. $\%$, the the carbide formation regularities are controlled by the quantity of vanadium nitrides. The quantitative laws are following for effect of vanadium nitride $\left(\mathrm{q}_{\mathrm{vN}(\mathrm{aust})}\right)$, which did not dissolve at heating for quenching: 


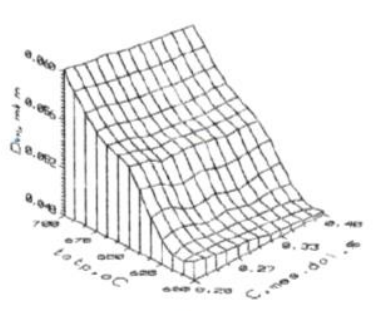

a

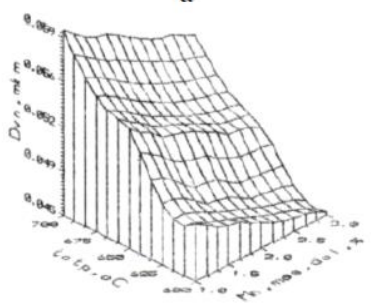

c

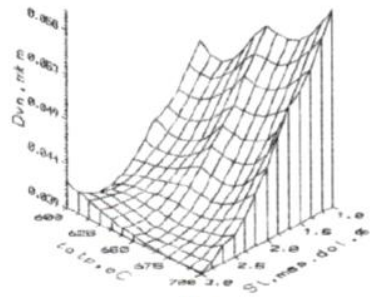

$\mathrm{b}$

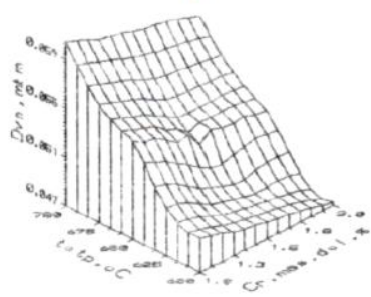

d

Fig. 15. The carbon (a), silicon (b), manganese (c), chromium (d) and tempering temperature influence on sizes of vanadium nitrides. $1 \mathrm{Cr}$.

The base steel contains (wt. \%) $0.2 \mathrm{C}, 1 \mathrm{Si}, 1 \mathrm{Mn}$,

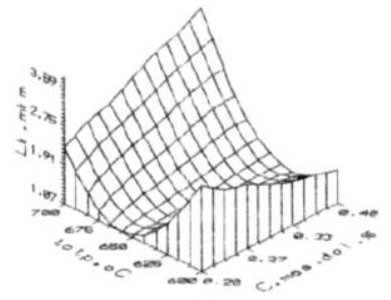

a

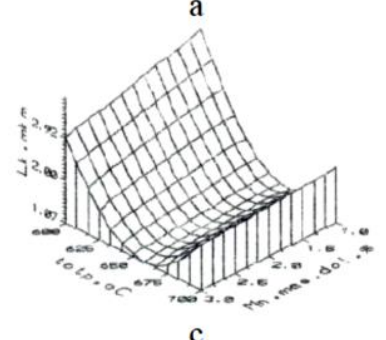

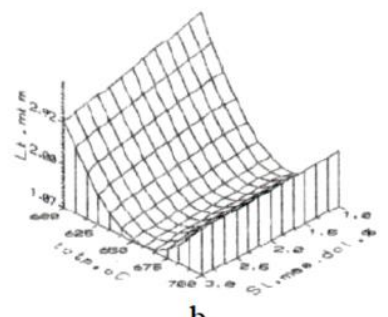

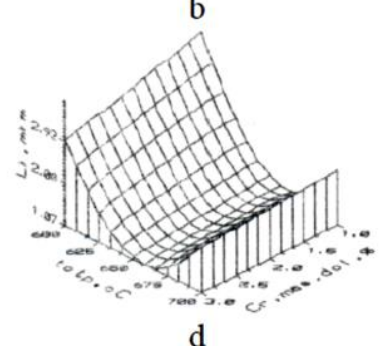

d

Fig. 16. The carbon (a), silicon (b), manganese (c), chromium (d) and tempering temperature influence on distance between carbides. $1 \mathrm{Cr}$.

The base steel contains (wt. \%) $0.2 \mathrm{C}, 1 \mathrm{Si}, 1 \mathrm{Mn}$,

$d_{c}=1-24,1 \cdot q_{V N(\text { aust })}+195 \cdot q_{V N(\text { aust })}{ }^{2}$,

$\mathrm{R}=0.972 ; \delta=1,8 \% ; \mathrm{F}_{\mathrm{p}}=16,8>\mathrm{F}_{\mathrm{T}}=9$.

$\lambda_{c}=1,5-12 \cdot q_{V N(\text { aust })}+1,9 \cdot 10^{-3} \cdot \lg [C]_{d} \cdot \ln D_{f}^{C},(10)$

$\mathrm{R}=0.974 ; \delta=2,4 \% ; \mathrm{F}_{\mathrm{p}}=18,2>\mathrm{F}_{\mathrm{T}}=9,0$.

A metallographic analysis shows that at alloying of structural steel by nitrogen and vanadium, there is not only dispersion of the carbide phase and an increasing of its the distribution uniformity (Fig. 17), but also a significant decreasing of structural heterogeneity.

For example, the Armco iron ferritic structure is grinded more than 2 times at alloying by nitrogen and vanadium (fig. $18 \mathrm{a}, \mathrm{b}$ ), and in the case of steel 40KhGS3L - 3.2 times (fig. 18 c, d). An even more effective effect is observed at alloying by nitrogen and vanadium of the steel 40KhGSL (fig. 18 e, f).

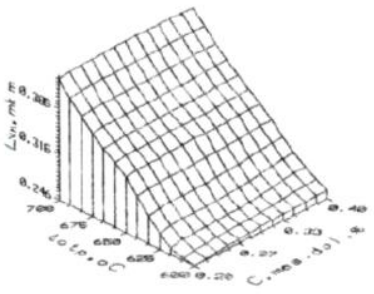

a

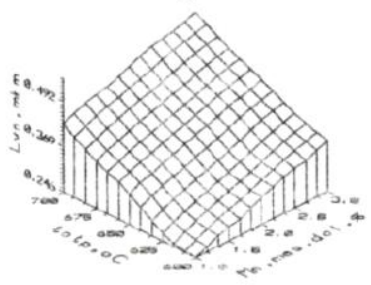

c

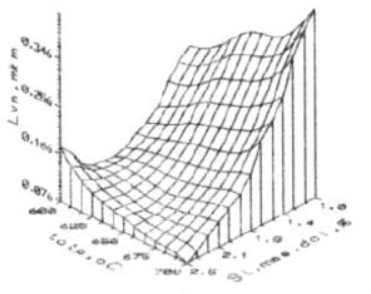

b

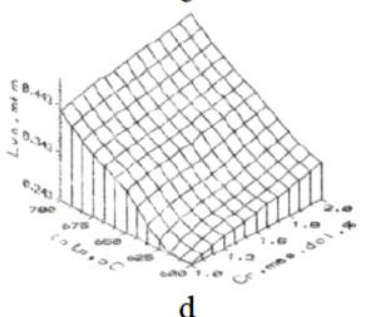

d
Fig. 17. The carbon (a), silicon (b), manganese (c), chromium (d) and tempering temperature influence on distance between vanadium nitrides.

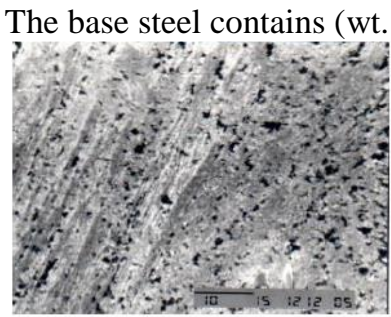

a

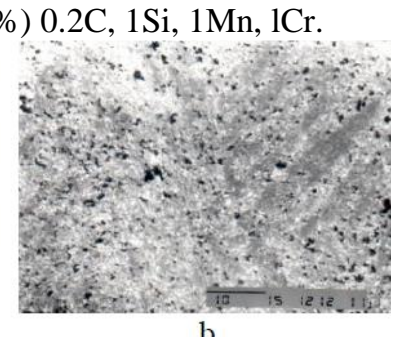

$\mathrm{b}$
Fig. 18. The carbidic phase in steel 20KhG3SL (a) and 20KhG3SAFL (b) after quenching of $950{ }^{\circ} \mathrm{C}$ and tempering at $650{ }^{\circ} \mathrm{C}$. Magnification -2000 times.
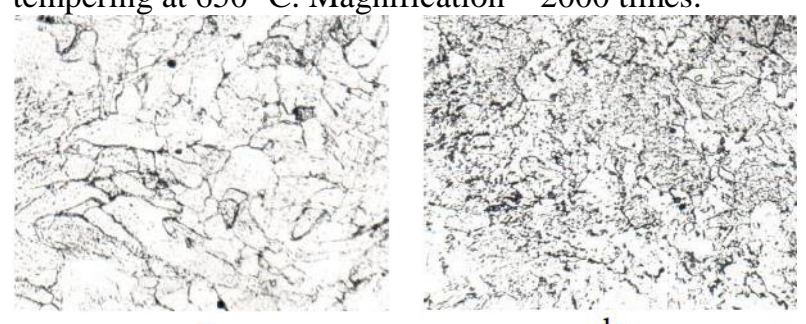

b
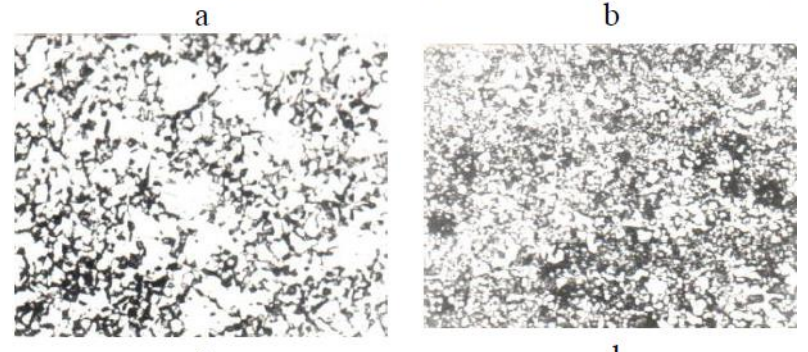

d

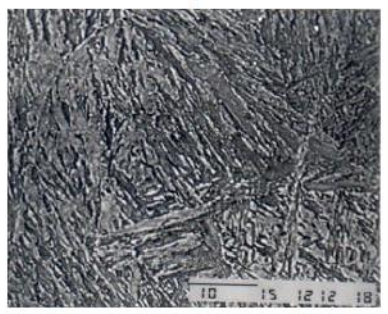

e

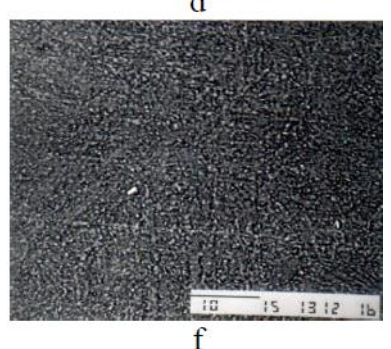

Fig. 19. Microstructure of Armco - iron $(a, b)$, steels 40KhGS3L (c), 40KhGS3AFL (d), 40KhGSL (e), 40KhGSAFL (f) after quenching of $950{ }^{\circ} \mathrm{C}$ and tempering at $650{ }^{\circ} \mathrm{C}$.

Magnification: a, b - 200 times; c, d - 100; e, f - 2000. 


\section{Conclusions}

1. The study showed that the influence of alloying elements on the secondary structure formation of the steels containing from 0.19 to $0.37 \mathrm{wt}$ \% carbon; 0.82-1.82 silicon; 0.63-3.03 manganese; 1.01-3.09 chromium; 0.0050.031 nitrogen; up to $0.25 \mathrm{wt} . \%$ vanadium and austenite grain size is determined by their change in the content of vanadium nitride phase in austenite, its alloying and overheating above $t_{a c 3}$, and the dispersion of ferritepearlite, martensitic and bainitic structures is determined by austenite grain size and thermal kinetic parameters of phase transformations. Analytical dependencies are defined that describe the experimental data with a probability of $95 \%$ and an error of $10 \%$ to $18 \%$.

2. An analysis results of studying the structure formation of structural steel during tempering after quenching show that the dispersion and uniformity of the distribution of carbide and nitride phases in ferrite is controlled at complete austenite homogenization by diffusion mobility and the solubility limit of carbon and nitrogen in ferrite, and secondary phase quantity in case of the secondary phase presence in austenite more than 0.04 wt. \%. Equations was obtained which, with a probability of $95 \%$ and an error of 0.7 to $2.6 \%$, describe the real process.

\section{References}

1. Guljaev B. B. (1976). Theory of foundry processes. Leningrad: Mashinostroenie. 228.

2. Goodremont E. (1959). Special steels. Moscow: Metallurgizdat. 1274.

3. Mes'kin V. C. (1964). Basics of alloying steel. Moscow: Metallurgija. 684.

4. Braun M. P. (1965) Complex alloyed structural steels. Kyiv: Naukova Dumka. 292.

5. Braun M. P. (1977). Economically alloyed steels for mechanical engineering. Kyiv: Naukova Dumka. 208.

6. Doerti R. D. (1987). Diffusive phase transformations in a solid material. Fizicheskoye metallovedeniye. Moscow: "Metallurgy". Vol. 2. 276-365.

7. Martin Dzh., Doerti R.D. (1978). Microstructure stability of metal systems. Moscow: Atomizdat. 280.

8. Kristian Dzh. U. (1968). Phase transformations. Fizicheskoye metallovedeniye Moscow: "Mir". Vol. 2. 227-346.

9. Bokshteyn B. S., Bokshteyn S. Z., Zhukhovitskiy A. A. (1974). Thermodynamics and kinetics of diffusion in solids. Moscow: Metallurgija, 280.

10. Kurdyumov G. V., Utevskiy L. M., Entin R. I. (1977). Transformations in Iron and Steel. Moscow: Nauka. 236.

11. Van Flek L. (1975). Theoretical and Applied Materials Science. Moscow: Atomizdat. 472.

12. Umanskij Ja. S., Skakov Ju. A. (1978). The physics of metals. Moscow: Atomizdat. 352.

13. Yershov G. C., Bychkov Yu. B. (1982). Physical and chemical bases of rational alloying of steel and alloys. Moscow: Metallurgija. 360.

14. Kreshchanovskiy N. S., Sidorenko M. F. (1970). Steel modification. Moscow: Metallurgija. 296.
15. Blanter M. Ye. (1984). Heat treatment theory. Moscow: Metallurgija. 328.

16. Ustinovshchikov Yu. I. (1988). Second phase precipitation in solid solutions. Moscow: Nauka. 172.

17. Bokshteyn B. S., Kopetskiy I. V., Shvindlerman L. S. (1986). Thermodynamics and kinetics of grain boundaries in metals. Moscow: Metallurgija. 224.

18. Grabskiy M. V. (1972). The structure of grain boundaries in metals. Moscow: Metallurgija. 160.

19. Kaybyshev O. A., Valiyev R. Z. (1987). Grain boundaries and metal properties. Moscow: Metallurgija, 214.

\section{Список літератури}

1. Гуляев Б. Б. Затвердевание и неоднородность стали. Москва. Металлургиздат, 1950. 228 с.

2. Гудремон Э. Специальные стали. Москва. Металлургиздат, 1959. $1274 \mathrm{c}$.

3. Меськин В. С. Основы легирования стали. Москва. Металлургия, 1964. 684 с.

4. Браун M. П. Комплекснолегированные конструкционные стали. Киев: Наукова думка, 1965. 292 c.

5. Браун М. П. Экономнолегированные стали для машиностроения. Киев: Наукова думка, 1977. 208 с.

6. Доэрти P. Д. Диффузионные фазовые превращения в твердом теле. Физическое металловедение. Москва. Металлургия, 1987. т.2. C. 276-365.

7. Мартин Дж., Доэрти Р. Д. Стабильность микроструктуры металлических систем. Москва. Атомиздат, 1978. $280 \mathrm{c.}$

8. Кристиан Дж. У. Фазовые превращения. Физическое металловедение. Москва. Мир, 1968. т. 2. C. 227-346.

9. Бокштейн Б. С., Бокштейн C. 3., Жуховицкий $A$. A. Термодинамика и кинетика диффузии в твердых телах. Москва. Металлургия, 1974. $280 \mathrm{c}$.

10. Курдюмов Г. В., Утевский Л. М., Энтин Р. И. Превращения в железе и стали. Москва. Наука, 1977. $236 \mathrm{c}$.

11. Ван Флек Л. Теоретическое и прикладное материаловедение. Москва. Атомиздат, 1975. 472 с.

12. Уманский Я. С., Скаков Ю. А. Физика металлов. Москва. Атомиздат, 1978. 352 с.

13. Ершов Г. С., Бычков Ю. Б. Физико-химические основы рационального легирования сталей и сплавов. Москва. Металлургия, 1982. 360 с.

14. Крещчановский Н. C., Сидоренко $\quad$ M. $\Phi$. Модифицирование стали. Москва. Металлургия, 1970. 296 c.

15. Блантер M. E. Теория термической обработки. Москва. Металлургия, 1984. 328 с.

16. Устиновщиков Ю. И. Выделение второй фазы в твердых растворах. Москва. Наука, 1988. 172 с.

17. Бокитейн Б. C., Копеикий И. B., Швиндлерман Л. С. Термодинамика и кинетика границ зерен в металлах. Москва. Металлургия, 1986. 224 с.

18. Грабский М. В. Структура границ зерен в металлах. Москва. Металлургия, 1972. 160 с. 
19. Кайбымев О. А., Валиев Р. З. Границы зерен и свойства металлов. Москва. Металлургия, 1987. 214 с.

\section{МОДЕЛИРОВАНИЕ ФОРМИРОВАНИЯ СТРУКТУРЫ В КОНСТРУКЦИОННЫХ СТАЛЯХ Е. Г. Афтандиляни \\ Аннотация. Исследованием влияния} легирующих элементов на процесс формирования вторичной структуры сталей, содержащих от 0,19 до $0,37 \%$ массовой доли углерода; 0,82-1,82 кремния; 0,63-3,03 марганца; 1,01-3,09 хрома; 0,005-0,031 азота; до $0,25 \%$ ванадия, установлено, что размер зерна аустенита определяется изменением ими содержания нитридванадиевой фазы в аустените, степени его легирования и перегрева над температурой $t_{a c 3}$, а дисперсность феррито-перлитной, мартенситной и бейнитной структур - размером зерна аустенита и термокинетическими параметрами фазовых превращений. Определены аналитические зависимости такого влияния, которые с вероятностью $95 \%$ и погрешностью от $10 \%$ до $18 \%$ описывают экспериментальные данные.

Анализом результатов исследования формирования структуры конструкционной стали в процессе отпуска после закалки установлено, что дисперсность и однородность распределения карбидной и нитридной фаз в феррите контролируется при полной гомогенизации аустенита диффузионной подвижностью и пределом растворимости углерода и азота в феррите, а в случае присутствия в аустените вторичной фазы более $0,04 \%$ мас. доли ее количеством. Получены уравнения такого влияния, которые с вероятностью 95\% и погрешностью 0,7-2,6\% описывают реальный процесс.

Ключевые слова: конструкционная сталь, химический состав, термическая обработка, аустенит, феррит, перлит, мартенсит, бейнит, фазовые превращения.

\section{МОДЕЛЮВАННЯ ФОРМУВАННЯ СТРУКТУРИ В КОНСТРУКЦІЙНИХ СТАЛЯХ \\ С. Г. Афтанділяни}

Анотація. Дослідженням впливу легуючих елементів на процес формування вторинної структури сталей, що містять від 0,19 до 0,37\% масової частки вуглецю; 0,82-1,82 кремнію; 0,63-3,03 марганцю; 1,013,09 хрому; 0,005-0,031 азоту; до 0,25\% ванадію, встановлено, що розмір зерна аустеніту визначається зміною ними змісту нітрид ванадієвої фази в аустеніте, ступеня його легування і перегріву над температурою $\mathrm{t}_{\mathrm{ac} 3}$, a дисперсність феррито - перлітної, мартенситної $\mathrm{i}$ бейнітної структур - розміром зерна аустеніту і термокінетичними параметрами фазових перетворень. Визначено аналітичні залежності такого впливу, які з ймовірністю 95\% і похибкою від 10\% до 18\% описують експериментальні дані.

Аналізом результатів дослідження формування структури конструкційної сталі в процесі відпуску після гартування встановлено, що дисперсність і однорідність розподілу карбідної і нитридної фаз в фериті контролюється, при повній гомогенізації аустеніту, дифузійної рухливістю і межею розчинності вуглецю і азоту в фериті, а в разі присутності в аустеніті вторинної фази більш 0,04\% мас. долі іiі кількістю. Отримані рівняння такого впливу, які 3 ймовірністю 95\% i похибкою $0,7-2,6 \%$ описують реальний процес.

Ключові слова: конструкційна сталь, хімічний склад, термічна обробка, аустеніт, ферит, перліт, мартенсит, бейніт, фазові перетворення.

\section{Є. Г. Афтанділянц ORCID 0000-0003-2681-0645.}

